\title{
China's Power Sector
}


This page is intentionally left blank 


\title{
EAl Occasional Paper No. 12
}

\section{China's Power Sector}

\section{John WONG WONG Chee Kong}

\author{
EAST ASIAN INSTITUTE \\ National University of Singapore
}

\section{World Scientific}

Singapore - New Jersey • London • Hong Kong 


\section{Published by}

World Scientific Publishing Co. Pte. Ltd.

P O Box 128, Farrer Road, Singapore 912805

USA office: Suite 1B, 1060 Main Street, River Edge, NJ 07661

UK office: 57 Shelton Street, Covent Garden, London WC2H 9HE

and

Singapore University Press Pte. Ltd.

Yusof Ishak House, National University of Singapore

10 Kent Ridge Crescent, Singapore 119260

\section{CHINA'S POWER SECTOR}

\section{EAI OCCASIONAL PAPER No. 12}

Copyright $\odot 1999$ by World Scientific Publishing Co. Pte. Ltd. and Singapore University Press Pte. Ltd.

All rights reserved. This book, or parts thereof, may not be reproduced in any form or by any means, electronic or mechanical, including photocopying, recording or any information storage and retrieval system now known or to be invented, without written permission from the Publishers.

For photocopying of material in this volume, please pay a copying fee through the Copyright Clearance Center, Inc., 222 Rosewood Drive, Danvers, MA 01923, USA. In this case permission to photocopy is not required from the publishers.

ISBN $981-02-3860-6(\mathrm{pbk})$

Printed in Singapore. 


\section{CONTENTS}

Powering China's Dynamic Growth 1

Growth and Adjustment of China's Power Industry 13

China's Power Mix 19

The Need for Price Reform 22

Scope for Foreign Participation? $\quad 27$

Appendix 1: Forecasting China's Demand for Electricity 29 